\title{
LEGAL RUSSIAN IN LEGAL - LINGUISTIC RESEARCH
}

\author{
Marcus GALDIA \\ International University of Monaco \\ mgaldia@monaco.edu
}

\begin{abstract}
The article focuses upon the emergence and the development of the legal Russian language and the methodology used for its scrutiny in the legal-linguistic research in Russia and abroad. It shows some of the dominant tendencies in the legal-linguistic and related research in a perspective that combines material issues concerning the work on textual sources and their identification as well as methods developed in Russia to deal with legallinguistic problems. The author aims to portray methodological continuity and discontinuity in a research area with a relatively long history. The overview of topics and methods demonstrates that the development in the area of the legal-linguistic research in Russia displays all characteristic features of the European legal-linguistic tradition, and especially the shift in the attention of scholars from isolated terminological issues to discursive aspects of law.
\end{abstract}

Key words: legal Russian, legal terminology, comparative legal linguistics, legal discourse 


\section{Marcus GALDIA: Legal Russian in Legal...}

Streszczenie: Artykuł traktuje o kształtowaniu i rozwoju języka rosyjskiego prawa oraz o metodologii stosowanej w studiach legilingwistycznych w Rosji i za granicą. Autor ilustruje tendencje dominujące $w$ badaniach legilingwistycznych i badaniach zbliżonych do nich koncentrując się na problemach dotyczących identyfikacji materiałów zródłowych oraz metod stworzonych w Rosji dla potrzeb analiz legilingwistycznych. Autor charakteryzuje również kontynuację i dyskontynuację w metodyce badań legilingwistycznych mającą w Rosji znaczny dorobek historyczny. Poniższy przegląd problemów i metod badań legilingwistycznych w Rosji wykazuje cechy charakterystyczne dla europejskiej tradycji legilingwistycznej, szczególnie transformację zainteresowań badaczy począwszy od analizy terminologii $w$ izolacji od innych implikacji lingwistycznych do dyskursywnych aspektów prawa.

Słowa kluczowe: rosyjski język prawny, terminologia prawnicza, legilingwistyka porównawcza, dyskurs prawny

\section{Approaches to legal Russian language in legal-linguistic research}

Traditional research approaches to the legal Russian language in Russia were dominated by the methodological divide into spoken and standard literary language. This research tradition was adopted in Russian linguistics relatively early, at the beginning of structuralist and formalist movements in humanities that can be traced back to the twentieth of the $20^{\text {th }}$ century (Broekman 1971: 47-54). The approach to standard language that was perceived as divided into spoken and literary varieties continued to dominate the research in Soviet times and it is also preponderant in many contemporary Russian linguistic studies (cf. Lehmann 2013). Meanwhile, before the Soviet revolution, positivist, historical and etymological interests as well as editorial philology of older Russian legal texts marked the methods of the academic research into the formation and development of legal Russian (cf. Jagić 1910/2003: 148-149, Stang 1939, 1952). This research focused mainly on philological problems in editing documents known as sources of legal history; the element of linguistic analysis in them was therefore often rather rudimentary (Koshkin 2008: 5). Some eminent works by Russian and foreign authors such as Goetz (1916), Miklosich (1888), Napierski (1868), and Shahmatov 
(1886) are also construed in this vein. They are therefore interesting as sources for legal-linguistic research that deals with diachronic aspects of the legal language rather than as results of such research. Meanwhile, all such works beginning with J.P.G. Ewers's (1826) pioneering monograph on the eldest Russian law include references to the legal language. For instance, Ewers (1826: x-xi) analyses the terms dushegubstvo (душегубство) and ubijstvoluboj (убїиство/убой) and determines the chronology of their upcoming. He also mentions that the eldest Russian legal texts distinguished already between negligent and intentional acts. Equally, epistemic interests that would be today qualified as discursive are present in Ewers's research, especially in confronting sources that seem to be linguistically structured by the necessity to legitimize the exercise of power in the new Russian state such as the Nestor's Chronicle (Ewers 1826: 25-29). The research paradigm initiated by Ewers and other Russian historians and philologists continued throughout the last decades of Imperial Russia. Also later structuralist and formalist approaches have their roots in the research paradigms that focused on diachronic aspects of law and its language. Additionally, in Soviet Russia, also semiotic and formalized approaches to the legal language shaped the researchers' level of problem awareness. They led to the increased interest in formal aspects of the legal language (cf. Pigolkin 1990). Today, mainly structuralist and post-structuralist approaches as well as semiotic studies that include philosophical and linguistic pragmatics of AngloAmerican origin are present in the Russian legal linguistics (cf. Golev 2004, Korolev 2010, Dubrovskaya 2010, 2014). Meanwhile, corpusbased historical and terminological investigations continue the research tradition initiated already in Imperial Russia.

\section{Legal linguistics in the Russian Federation and beyond}

The term juridicheskaja lingvistika (юридическая лингвистика) for legal linguistics is largely used in contemporary research in the field (cf. Goletiani 2011: 242, Mattila 20017: 13). L. Goletiani (2011) perceives the Russian legal linguistics as a multifaceted field where areas such as legal stylistics, forensic phonetics, legal translation, legal terminology, the understanding of the language of legislation, the history of legal language, speech in the 


\section{Marcus GALDIA: Legal Russian in Legal...}

courtroom etc. are represented in publications and methodological approaches. Previous, Soviet time research referred rather to statutory language (jazyk zakona /язык закона) (cf. Pigolkin 1990). Among the main achievements of this period that was dominated by semiotical perspectives and attempts at formalization of the legal language are the elucidation of explicit semantic aspects of statutory language and the prevalence of meaning-related studies over form-centered textological analyses. In this research the concealed, implicit element of meaning was identified as the main problem in interpretation and application of legal texts (Pigolkin 1990: 180-188). Latent or implicit information in normative texts was perceived as acceptable solely under conditions of text economy where meaning can be easily inferred from the totality of legal acts. This is rather a rare case and therefore the researchers claimed the necessity to increase the explicit component of normative acts. Broad paradigmatic research programmes were also developed by A.S. Aleksandrov (2003) and by N.S. Plotnikova (2010) who combined history of language and discourse analysis. Earlier, N.A. Vlasenko (1997) proposed an overview of the Russian law in semiotic perspective (cf. Mattila 2012: 13). He also stressed the interrelation between the textual form of the expression of law and its logical structure. By so doing, he aptly combined doctrinal and legal-linguistic problems showing the embeddedness of law in broader semiotic practices. Meanwhile, doctrinal aspects of law are nowadays less present in the Russian legal-linguistic research than in Vlasenko's monograph. Currently, pragmatically oriented research is gaining momentum in Russia. Research by N.D. Arutiunova, N.K. Rjabceva et al (1995), A. Zaliznjak, I. Levontina, A. Shmelev (2002), N.S. Plotnikova et al (2010), and T. Dubrovskaya $(2010,2014)$ make use of discourse analysis and pragmalinguistic methods. Analyses of media discourse about legal matters that shows paradoxical attitudes towards judicial power in the contemporary Russian society is also present (cf. Dubrovskaya, Dankova, Gulyaykina 2015). Discourse analysis and speech act theory are fundamental to Russian legal linguistics developed abroad by G. Freidhof $(1995,1996)$. Forensic linguistics is actually the most visible part of the Russian legal linguistics within Russian judicial institutions (cf. Mushchinina 2009: 23-24). In this area, co-operation between legal linguists and courts is increasing, mainly regarding defamation cases - libel and slander - as well as hate crimes (cf. Kusov 2004). The Russian-language journal 
Jurislingvistika (Юрислингвистика) publishes since 1999 legallinguistic research from all over the Russian Federation.

\section{Russian legal language}

Some of the above mentioned approaches to the Russian legal language from the beginning of the $20^{\text {th }}$ century resulted in the determination of its linguistic status as a sub-genre of the standard literary language in the structuralist research (cf. Bartoszewicz 1979: 80). In this view, the legal sub-genre of the standard literary language is characterized by a specific style. Therefore, in the research committed to the textological perspective, oral samples were contrasted with the language of written documents. The main result of the traditional research relevant to the development of modern approaches to the legal language was the finding that in legally relevant linguistic surroundings functional linguistic change dominates over structural change (Bartoszewicz 1979: 16). The reason for this regularity was seen in the circumstance that function is determined by the sphere of language use. This result paved the way to a research perspective that focuses on language use in legally relevant communicative situations. Interestingly, and unlike in the Polish legal linguistics, neither in the Soviet times nor in post-Soviet Russia the very existence of the legal language has been ever questioned in the debate about the characteristic features of the legal language (Pigolkin 1990: 16-17, Galdia 2017: 78).

\section{Linguistically relevant written sources of Russian law}

Material analyses of written legal sources concerned from the very inception of legal-linguistic or related historical and philological research in Russia historically influential statutory texts that form the legal fundaments of the Russian society and its state. They do not always coincide with the listing of fundamental legal documents in the history of the Russian law as the importance of a historical document 
does not always reflect its linguistic status in the history of the development of the legal language.

Old Russian law can be found in different editions of Russkaja Pravda (Русская Правда) from $11^{\text {th }}-12^{\text {th }}$ centuries (Obnorskij 1934). Russkaja Pravda is a compilation of different older texts such as Zakon Russkij (Закон Русский), Pravda Jaroslava Mudrogo (Правда Ярослава Мудрого), Pravda Jaroslavichej (Правда Ярославичей), Ustav Vladimira Monomaha (Устав Владимира Монамаха) and some others. It is known from different editions dating between $13^{\text {th }}$ and $18^{\text {th }}$ centuries. The text has been edited in subsequent short, long, and abbreviated versions. It regulated issues such as protection of life and property belonging to the members of the ducal court and army servicemen as well as the legal status of free inhabitants of towns and villages. It also regulated the legal position of all dependent people. In the area of private law, it mainly dealt with obligations and inheritance.

The main textual components of Russkaja Pravda are interesting also in isolation. Zakon Russkij represents the customary law dating back to $9^{\text {th }}-10^{\text {th }}$ century. It unites the provisions of the East Slavonic tribes and their later territorial unit known as the Kievan Rus (Киевская Русь). It can be further traced in two treaties with Byzantine Greeks from 911 and 944 as well as in relevant parts of the Russkaja Pravda. Zakon Russkij regulated areas pertaining to penal, inheritance, family, and procedural law. The original version of Russkaja Pravda is the short form dating back to the 11th century. It was compiled in Novgorod in times of the rule of Jaroslav the Wise. The original edition is lost today. Later versions of the short edition can be found in the First Novgorod Chronicle (Первая Новгородская Лeтопись) from $15^{\text {th }}$ century. The eldest text of the long or full edition is documented in the legal code Novgorodskaja Kormchaja (Новгородская Кормчая) from 1282. In the text type kormchyje knigi (кормчие книги), which are based on the Nomokanon representing the religious law of Byzantine origin, the influence of Byzantine law upon the Russian law is manifest. Nomokanon is dominated by the religious law of the Orthodox Church, yet it includes also provisions relevant to secular life. Unlike later legal codes, Russkaja Pravda does not reveal its origins. It could have been written on sovereign's command to serve as a code for the country or it could have been a private collection of laws that acquired esteem and general public approval in later times (cf. Platonov 1917: 111). I.S. Koshkin (2008: 21) mentions 
the view rendered already in E.F. Karskij's Russkaja Pravda po drevniejsheти spiskи (Русская Правда по древнейшему списку) that the text of the Pravda is a reformulated and not simply a written down compilation of customary legal rules of mostly North-Germanic origin. This and related views will forever remain conjectures; yet it can be assumed that the Pravda follows notional and textual patterns known from other legal traditions. The text is furthermore all but complete in terms of regulation. For instance, it does not include any regulation of land use. This circumstance led some scholars to the belief that originally arable land had been in common use in Russia (cf. Ewers 1826, Platonov 1917: 69).

Typical of the legal language in the legal documents and other relevant artefacts such as Russkaja Pravda is the predominance of the ordinary Russian language over the otherwise largely used Old Church Slavonic language that dominates religious texts and parts of secular literary contributions (cf. Unbegaun 1957). A parallel phenomenon is known in comparative legal linguistics from the legal Spanish. There, Las Siete Partidas are composed in ordinary Spanish that avoids direct borrowings from the legal Latin (cf. Galdia 2014: 272). Local languages and not legal Latin shaped the linguistic dress of Las Siete Partidas as did local languages for Russkaja Pravda. This particularity may be partly explained by the formation process of legal provisions that emerged orally in the local languages and were only later fixed in writing (Bartoszewicz 1979: 51). Also the necessity to understand legal provisions in broader social strata limited the use of the Church Slavonic language in legal documents (Selishchev 1957: 59). B.O. Unbegaun (1969) underscored that Old Church Slavonic terminology is not only absent in Russkaja Pravda but also in Codes of feudal law, called Sudebniki (Судебники) from 1497, 1550, 1589 and in the Code of the tsar Alexey Mihailovich (Соборное Уложение иаря Алексея Михайловича) from 1649, which was the first Russian Code to appear in print (Chernyh 1953, Glötzner 1967). It is composed of 25 chapters embracing 983 articles. Some researchers argue therefore that legal texts of the old Russian laws have been put in writing in their more or less original form, which goes back to times before the Christianization of the Rus and the introduction of the Church Slavonic language on its territory (cf. Bartoszewicz 1979: 53).

Research into older forms of the legal Russian concerned also documents other than codifications of laws such as the above mentioned Russkaja Pravda. Contracts and agreements of the public 
law, donation acts, last wills, and complaints to authorities are characterized by the standardized use of language that tends towards repetitive use of legal formulas. This research also stresses the unifying force of different standardized legal texts on the territory of the Kievan Rus that strengthened the trend towards forming a singular linguistic norm to the detriment of regional legal-linguistic particularisms (Bartoszewicz 1979: 79)

Beyond Russkaja Pravda and Ulozhenije carja Alekseja Mihailovicha, the collection of statutes Polnoye sobranie zakonov Rossijskoj Imperii (Полное собрание законов Российской Империи) represents the fullest collection of pre-revolutionary Russian law in chronological order. The first collection from 1830 comprises 45 volumes and appendices relating to laws from 1649 to 1825 . The second collection that appeared in print from 1830 to 1884 comprised the laws from 1830 to 1881 in 55 volumes. The third collection was edited until 1913 and it presented the laws from 1881 to 1913 in 33 volumes. All in all, the collection comprised ca. 150.000 legal acts in more than 150 volumes with appendices and registers. In the meantime, Svod zakonov Rossijskoj Imperii (Свод законов Российской Империи) that appeared in three editions 1832, 1842, and 1857 compiled the law in force in Russia at the time of its appearance in print according to a classification by topics. Linguistically, it represents a Europeanized legal Russian based on Latin, French, and German terminology.

Due to their unproportional number in relation to other written sources relevant to the inquires into the past, the historian S.F. Platonov proposed to classify the sources of the Russian law according to their importance for history (Platonov 1917: 54-56). He distinguished Russian State papers, administrative documents, requests addressed to the government, documents relating to civil litigations, court documents, especially court opinions and prikaznyje knigi (приказные книги) that included guidelines for administrative institutions. For the old Russian law, different types of documents (gramoty/грамоты) are genre-constitutive. Platonov (1917: 54-56) distinguished dushevnye g. (душевные г.) last wills of dukes, administrativnye g. (административные г.) guidelines for particular administrative agencies, ustavnye i gubnye g. (уставные и губные г.) that concern regional territorial units. Some textological specifics can be also found in books, e.g. kormchye knigi (кормчие книги) (Nomokanon, i.e. religious laws of the Orthodox church), prikaznye 
knigi (приказные книги) that included ukaznye knigi (указные книги) with legal orders for the administration, piscovye knigi (nисиовые книги) that described real property, knigi perepisnye (книги переписные) that listed tax payers, knigi kormlennye i desjatni (книги кормленные и десятни) that listed persons belonging to the Imperial court, knigi razrjadnye (книги разрядные) and dvorcovye knigi (двориовые книги) that listed the nobility and public servants according to their ranks. The whole public service, military and civil, was devided into ranks (chiny/чины) that were defined in the Rank Tables (Табельи о рангах) that distinguished 14 classes. The Rank Tables are important even today as the classical Russian literature that abounds in ranked protagonists is not understandable without a glimpse of the Tables.

\section{Legal terminology}

Next to syntactic particularities that form the core of the Russian legal style perceived by many Russian researchers rather unconvincingly as neutral (нулевой стиль), also professional terminology is traditionally perceived as characteristic of the Russian legal language (cf. Vlassenko 1997: 19, Casertano 2008: 226, Mattila 2012: 127). Legal terms that emerged orally in the pre-feudal epoch of clan- and tribal organization on the territory that later became Kievan Rus cannot be determined with the necessary certainty. Terms such as pravda (правда) for legal code, sud (cyd) for legal procedure (Smirnov/Manukyan 2008: 28, Pigolkin 1990: 44), and golovnik (головник) for murderer stem from the earliest period of the development of the legal Russian (cf. Ewers 1826: 12). Subsequent written legal documents may therefore be perceived as a mixture of traditional, orally shaped terminology and later coinages and borrowings from other legal cultures. Original old Russian terms in the period of feudal law are also typical of its time. In the emerging family law the term pridanije (придание) refers to the possession of the spouse, len (лен) is the liege of Eastern Europe, and desjatina (десятина), mentioned ca. 950, is the dime owned to the church. Also the Magdeburg town law introduced 1324 in Russia formed the terminology of the public law. Some later terms, such as kabala (кабала) - dependence due to debts or written certificate of debt (cf. 
Vasmer 2003) are probably of Turkish origin. Some other terms such as karaul (караул), kazna (казна), tamozhnja (таможня), jarlyk (ярлык) are of Tatar origin (Pigolkin 1990: 45). Interestingly, some of the traditional terms such as istec (ucmeu) for plaintiff and poshlina (пошлина) meaning tax are still in use in the Russian legal language (Casertano 2008: 237).

Some researchers stress the lack of terminological borrowings from Byzantine Greek in elderly legal documents such as Russkaja Pravda, while others advance more moderate opinions upon the question of possible borrowings (cf. Milov 1999: 137). In fact, borrowings in the legal language come in two types that originate in foreign terms and foreign concepts. Conceptual borrowings are less visible in written texts than terminological borrowings. Meanwhile, conceptual borrowings provide intellectual and textual patterns in which the law that benefits from such transfers finally develops. Therefore, the assumption advanced by some Russian scholars as to the role of the Byzantine law and the Roman law in Greek translation for the development of the ancient Russian law deserves to be supported. Likewise, Scandinavian and Gothic lexical borrowings in old Russian such as myt (мbım, commercial tax), tyn (mын; fence), vira (вира; fine), grid' (гридь; warrior), tkun (ткун; ducal official), and golvazhnja (голважния; a measure for salt) witness to ancient regional contacts between the Eastern Slaves and their Germanic neighbours (Bräuer 1961: 98, Bartoszewicz 1979: 52, Vasmer 2003). Medieval written legal texts in Russian were analysed in comparative perspective - including mainly Middle Low German - by I.S. Koshkin (2008). Koshkin demonstrated that the formulas and syntagmas of the Middle Low German shaped the Russian language used in legal documents in times relevant to his research. Syntagmas such as dobrye ludi (добрые люди/good people) became a textual pattern in Russian legal texts of that time. In this context, one can refer to parallel circumstances of use of the term in the American state papers (Galdia 2014: 294). As so often, the term as such was borrowed from legal Latin where terms boni homines, boni viri, probi viri were in general use (cf. Koshkin 2008: 129). This example illustrates that in the Middle Ages the legal Russian language was systematically - also in terms of the legal doctrine - exposed to linguistic and intellectual influence from the Roman law (cf. Casertano 2008: 212).

Beginning with the epoch of Peter the Great (1682 - 1725), Russian legal language was shaped mainly according to French and 
German linguistic usages. Borrowings such as: apellacija (апелляция), verbalnaja nota (вербальная нота), kadastr (кадастр), kassacija (кассация), kodeks (кодекс), kodifikacija (кодификация), kontribucija (контрибуция), novella (новелла), pakt (пакт), patent (патент), proskripcija (проскрипџи), reglament (регламент), reskript (рескрипт), sankcija (санкция), status (cmamyc), statut (статуm), suveren (суверен), and hartija (хартия) were in general use. Meanwhile, specific Russian terminology was equally used: chelobitie (челобитие), gubnyje gramoty (губнье грамоты), dannye gramoty (данные грамоты), zhalovannye graтоту (жалованные грамоты), kabala (кабала), krugovaja poruka (круговая порука), pravo (право), sloboda (слобода), sudebnik (судебник), tjaglo (тягло), ukaz (указ), ulozhenije (уложение), vojevoda (воевода), volost' (волость), ијеzd (уезд), zakon (закон). In legal texts of this and contiguous epochs both lexical groups were frequently mixed, for instance in a statute regulating the rights of the imperial family called Uchrezhdenije ob imperatorskoj familii (Учреждение об императорской фамилии) known in two versions from 1797 and 1886. This is also the case today, for instance in the Patent Law from 2003 (Патентный Закон).

Legal terminology reflects closely social processes also in Russia. In the Middle Ages, the term kabala as a legal position of unfree peasants is in frequent use. Towards the end of the $19^{\text {th }}$ century, in times of constant social unrest, terminology that reflects the security of the state becomes dominant: strengthened protection of public life for usilennaja ohrana (усиленная охрана/reinforced protection) (1881), limiting the transparency of court proceedings known as glasnost suda (гласность суда) (1887) or prohibiting harmful printed matters, vrednye izdanija (вредные издания) (1879), compulsory death sentence for political crimes in military courts, objazat'elnyi smertnyi prigovor (обязательный смертный приговор) (1887) are characteristic coinages of this period. The legal style that reaches beyond pure terminology was called in Imperial Russia prikaznoj jazyk (приказной язык). Contemporary legal Russian language takes its final shape in the timeframe between the $17^{\text {th }}$ and the mid $19^{\text {th }}$ centuries where it stabilizes in a linguistic form that is in general use today.

In the Soviet Union attempts have been undertaken to develop a new legal language (Pigolkin 1990: 10). Meanwhile they were also in the main given up at an early stage, with the exception of some 
ambitious linguistic neologisms such as obshchenarodnoje dostojanie /общенародное достояние for people's property (Casertano 2008: 253) or abbreviations with ideological background such as пастеп/наимен for nacjonalnoye menshinstvo (национальное меньшинство) meaning national minority (cf. Pigolkin 1990: 49-52, Casertano 2008: 238, Sokolovskij 2004: 80-100). This result is not surprizing as the abstract legal language is sematically easily adaptable to changed ideological conditions of its institutional application (cf. Galdia 2017: 365). Meanwhile, ideological influence upon the legal language during the Soviet time was omnipresent. For instance, a term such as intellektualnaya sobstvennost'\% интеллектуальная собственность for intellectual property was negatively connotated and therefore avoided (Mushchinina 2009: 25). It has been taken up again only in the nineties of the past century. Meanwhile, the traditional legal Russian language based on the spirit and terms of the Roman law and on French borrowings proved to be efficient even under changed social reality of the totalitarian Soviet state.

Today, work on the teminology of the Russian Civil Code dominates the research in the area of contrastive and comparative legal-linguistic studies, especially in relation to the Russian-English translations of the Code (cf. Sysoeva/Sobolev 2014). It has been stressed that next to terminology also structural aspects of codification, especially concerning the Russian Civil Code (Parts I and II) have been relevant to modern developments in Russia. Particularly the Dutch and the Canadian experience were prolific in this respect (cf. Casertano 2008: 245). Legal English lives in the Russian legislation the life of its own. For instance, Art. 213 of the Penal Code refers to huliganstvo (хулиганство) defined as violation of social order and Art. 214 adds to it vandalizm (вандализм) construed as destruction of public property. The Code of Administrative Offences, Kodeks ob administrativnyh pravonarushenijah (Кодекс об административньхх правонарушениях) refers in Art. 3.11 to diskvalifikacja (дисквалификаичя) as a sanction prohibiting the exercise of certain professions or public functions. Zonirovanije (зонирование/zoning) is one more borrowing from legal English. In its Art. 1.5 the Code mentions prezuтрсіja nevinovnosti (презумпиия невиновности), a possible French or English borrowing. Meanwhile, the common law term trust has been initially absorbed as mpacm, yet in the Civil Code transformed into doveritelnoe upravlenije 
(доверительное управление), illustrating thus a tendency towards coining Slavonic-based legal terminology (Casertano 2008: 216). Some legal texts are dominated by foreign borrowings. For instance, in a short passage of a Russian text all terms may be loanwords: zona (зона), komissija (комиссия), status (статус), konstrukcija (конструкиия), protokol (протокол), akt (акт) (cf. Vlasenko 1997: 29). In a dictionary of private law terms Словарь Гражданского Права by V.N. Dodonov, E.V. Kaminskaja and O.G. Rumjancev (1997) all entry words listed under the letter A are loan words, mostly from Latin or French. Synonyms are frequent in legal Russian; Vlasenko (1997: 65) indicates seven synonyms for contract (договор, контракт, соглашение, пакт, конвенция, консенсус, ангажемент). Syntagmas of the legal Russian are regularly part of the common European legal language, e.g. za nedostatkom ulik/3a недостатком улик and German wegen Mangels an Beweisen for (dismissed) for lack of evidence. Such comparative legal-linguistic examples prove that the legal Russian language adopted linguistic mechanisms that facilitated its uniformization in line with the developments in the rest of the European continent. Countertendencies aiming at building terms based upon Slavonic roots or legal particularisms such as lesnoj fond (лесной фонд) of the Forest Code (Лесной Кодекс) lead as a rule to interpretive and translational problems (cf. Lehtinen 2008: 183). Regularly such particularisms make also the monitoring of legislative acts of the Russian Federation cumbersome from the perspective of its compliance with international standards as legal neologisms tend to dissociate itself from standardized conceptual coinages generally used in the globalizing law. They are therefore particularly challenging for legal comparatists.

\section{Legal Latin and Roman law in Russia}

Interest in legal Latin and in the Roman law is surprisingly lively in Russia, when compared with other civil law countries. The Digests of the Corpus Iuris Civilis have been published in eight volumes in a bilingual Latin-Russian edition as Digesty Iustiniana (Дигесты Юстинияна/Digesta Iustiniani) between 2001 and 2006 to commemorate the $250^{\text {th }}$ anniversary of the establishment of the Lomonosov State University in Moscow. Russia is today one of very 
few countries where the Digests are accessible in printed form, both as original and as translation. Other countries that developed their law in close reflection upon the Roman law such as Italy and France limit the accessibility to Roman legal sources to internet platforms. In Russia, Roman law is often treated as authority even in contemporary works on the evolution of Russian law (cf. Rudokvas 2011, Casertano 2008: 219). This is a development very specific to Russia, as in other countries the actuality of the research into Roman law, especially in relation to unsolved legal issues is diminishing or even non-existent. As a first interpretive attempt to clarify this surprising situation one might offer the assumption that the need for certainty and clarity in legislation, perceived by some Russian jurists as urgent, apparently led them to hope that solid and unambiguous law could be better deducted from ancient sources. This is however a vain hope because contemporary legal problems can be solved only in discursive practices that focus on the state of social affairs as we know it today. Therefore, shortcomings in the functioning of discursive mechanisms in contemporary societies, Russia included, cannot be ovecome by reference to authorities of ancient times. Roman law will however continue to play a role in legal-linguistic and legal-epistemic research as the conceptual background or the grammar of law (cf. Husa 2012: 169, Dozhdev 2003: xvii).

\section{Influence of legal Russian upon other legal languages}

The legal Russian language was mainly productive on the territory of the Russian Empire and later in the Soviet Union. Its most decisive influence can be seen in the formation of legal terminology of many minority languages spoken on Russia's territory. Many of these languages borrowed the Russian terminology directly, some used it to form linguistic calques. For instance, terms such as arbitrazh (арбитраж), gosudarstvennyi (государственный) or Soviet (Совет) have been incorporated directly into Mari (Galdia/Höpp 1993: 189). In the Chuvash language, terms such as atkas (аткас), āshtraf (aштраф), vakkat (ваккаm from Russian advokat), vinavat (винават), vulăs (вулас from Russian volost') are borrowings from Russian (cf. Fedotov, 1996). In smaller Caucasian languages (cf. Klimov/Halilov 2003), lexical units such as Abkhaz āsud (ācyd), 
Chechen and Ingush sud (cyd), Chamalal and Tindi sud (cyd) for court of law or legal proceedings are obvious borrowings from Russian. The same transfer process concerns the Russian word sud'ja (судья) (judge) in Abaza sudja (судя), Kabardian sudja (судя), in Lak sudja $(с у \partial я)$, in Darginian sudja (судя). In the Finnish language the borrowing suntio from $с у \partial ь я$ underwent a semantic change (cf. Bräuer 1961: 98). Also Russian shtraf (umpap for sanction or fine) was borrowed in Abkhaz āshtraf (äumpaф), in Kabardian shtraf (umpaф) and some other smaller languages. However, not only terminology but also textual patterns were borrowed from Russian, especially in smaller languages. Although detailed research into the issue is missing, it seems that Uralic languages spoken on the Russian territory were particularly exposed to the influence of the legal Russian. Meanwhile, the Russian legal language functioned as an instrument that formed official languages in all Republics as well as other languages spoken on the territory of the Soviet Union (cf. Pigolkin 1990: 144 - 147).

\section{Beyond legal terminology}

Problems of meaning emergence in written legal texts are a recurrent topic in Russian legal-linguistic research (cf. Burukina 2012). Especially polysemy and ambiguity have been explored in many works on the legal language that would probably define themselves as belonging to legal theory. Conceptual coinages such as dejstvie (действие) and bezdejstvie (бездействие) in Лицо подлежит уголовной ответственности только за те... действия (бездействие) и наступившие общественно опасные последствия, в отношении которых установлена его вина of the Penal Code (Art. 5) invite this sort of research. This dichotomy is also recurrent in the Art. 63 II of the Russian Constitution: В Российской Федераиии не допускается выдача другим государствам лии, преследуемых за политические убеждения, а также за действия (или вездействие) не признаваемые в Российскои Федерации преступленем. Excessive terminological exactness causes in both provisions unnecessary interpretive problems that could be easilly avoided through more explicit wording. Soviet and Russian legal theorists preferred rather methods of interpretation that are based on 


\section{Marcus GALDIA: Legal Russian in Legal...}

postulated decoding of meaning in legal provisions as shown in the overview by A. Smirnov and A. Manukyan (2008). In the legallinguistic research more interest have been shown towards constructive approaches to meaning constitution in legal texts (Dubrovskaya 2010). In both approaches interpretation as a legallinguistic operation occurs in relation to facts, when a specific norm shall be applied to a specific case and not when it is treated (i.e. read or reflected upon) in isolation from its act of application. The main difference between the two basic approaches to the semantic analysis of legal norms lies in the qualification of the interpretive operation as decoding of allegedly encoded message or construction of meaning that is based on policies and values of the moment. Dealing with this sort of understanding of legal norms leads into the problems of the legal discourse as an overarching construct of all semantic operations that are undertaken in order to shape and to understand law. Parallel developments that accompany such semantic inquiries concern the formalization of legal language (Pigolkin 1990: 25). In this area of the legal-linguistic research particular interest is directed towards explicitness of the legal message as implicit or imprecise and ambiguously drafted legal norms are an obstacle to attempts undertaken in the legal informatics to process and to systematize the language used in legal databases (cf. Pigolkin 1990: 151). Contemporary research that is construed in this vein is more detailed and comprises for instance analyses of deontic modality in the legal language (cf. Goletiani 2016).

\section{Legal Russian language in literary works}

As a rule, when the differentiated form of legal langue manifests itself significantly in professional and institutionalized use, it also appears in the literary practice in one way or another. Usually, literary connotations of legal language are mainly negative or ironical. The Russian literature fully supports this finding and examples of this transformation of the use of legal language abound in it. Some examples that follow below may illustrate this phenomenen of intralinguistic contact. They concern mainly parodies of legal language and its more existentially essential role, namely the oppressive language of power. 
As soon as the legal style and its terminology established itself in the Russian social practice, also its parodies emerged in the Russian literature, particularly in the $17^{\text {th }}$ century. Bartoszewicz (1979: 120) perceives following popular literary works as parodies of the Russian legal style: Kaljazinskaja chelobitnaja (Калязинская челобитная), Povest o Shemjakinom sudie (Повесть о Шемякином суде), Povest o Ershe Ershoviche (Повесть о Eрше Ерошовиче), Azbuki o golom $i$ ljubopytnom chelovekie (Азбуки о голом и любопьтном человеке), and Lechebniki kak lechit inozemcev (Лечебники как лечить иноземиев). They portray the social reality in contrast to the lofty language and ideals of the law that apparently had been rarely applied in the way in which it had been written. As mentioned, parodies of legal language are a textual constant in the legal discourse. Also the English language literature witnesses to the same dichotomy between the primary function of the legal language and its frequent parody (Galdia 2014: 326-327). Probably with this finding in mind, the specifics of the Russian legal culture have been synthesized by the writer Mikhail Evgrafovich Saltykov-Shchedrin in a frequently quoted ironical phrase: Суровость законов российских искупляется необязательностью их выполнения (The rigorour of the Russian laws is tempered by the optionality of their application)..

Legal language is also represented in more ambitious Russian literary works, for instance in F. Dostoyevsky's Crime and Punishment (Преступление и наказание) in a more existentially relevant context of oppression and opportunist professionalism. In Crime and Punishment its protagonist Raskolnikov admits his crimes in the legal style that stresses exactness or even explicitness: Это я тогда убил старуху-старевщицу и сестру её Лизавету топором и ограбил (I have then killed the old pawnbroker and her sister Elisabeth with an axe and robbed them). Historically, both Russian terms prestuplenije (преступление) and nakazanije (наказание) that form the title of Dostoyevsky's novel emerged in the process of modernization of the Russian legal terminology in the 17th century (cf. Pigolkin 1990: 46-47). Due to Dostoyevsky's work this somehow mechanistic dialectic of crime and punishment in the discourse about the penal law was deconstructed beyond expectations of his time and even beyond contemporary analytic capacities of jurists.

Particularly strong is also the interest of writers in the slang used by criminal elements and associated language varieties such as mat/мam (maternyj jazyk/матерный язык), a sort of particularly 


\section{Marcus GALDIA: Legal Russian in Legal...}

vulgar Cockney used both by criminals, soldiers, policemen and lower social strata. This language is also frequently used in contemporary literature and films with some reference to law. Meanwhile, today Art. 20.1 of the Code of Administrative Offences prohibits conduct that includes the use of obscene language in public and sanctions it by fines or arrest up to fifteen days: нарушение общественного порядка, выражающее явное неуважение $\kappa$ обществу, сопровождающееся нечензурной бранью в общественных местах ... влечет наложение административного штрафа в размере от пятисот до одной тысячи рублей или административный арест на срок до пятнадиати суток. It may be needless to mention that linguistic policy established in provisions of this sort is difficult to be applied in courts.

\section{Linguistic legislation in the Russian Federation}

Due to particularly complex linguistic diversity that is characteristic of the linguistic landscape of the Russian Federation the linguistic legislation on the federal and regional levels plays a special role there. In the Russian Federation over one hundred minority languages are in use next to the Russian language. The Constitution of the Russian Federation includes provisions of anti-discriminatory nature that unequivocally provide for the protection of minority cultures and minority languages, especially in its Art. 68 and 69. Unsurprisingly, the Constitution also establishes in its Art. 68 the Russian language as the State language of the Federation. The legal status of the Russian language was regulated 2005 in the Federal Law on the State Language of the Russian Federation (Федеральный Закон "О государственном языке Российской Федерации"). Overall, the linguistic legislation of the Russian Federation has been deemed acceptable in the light of international legal standards (cf. Galdia/Voronina 2004). Particularly well developed in Russia are legal standards in the area of minority education in minority languages. An overview of the linguistic legislation from RussianFrench comparative perspective was provided by E.I. Filippova (2013). Recently, also K. Zamyatin (2014) explored the relation between the official status of Finno-Ugric minority languages in 
Russia towards the background of the promotion of linguistic diversity:

\section{Conclusions}

The research into legal Russian when approached from the epistemological perspective shows several paradigmatic changes. The first one concerns the shift from positivist to post-structuralist and pragmatic methods. The other shows increasing interest in researching legal terminology in its discursive surroundings. Also present are perspectives upon legal language as a mechanism behind legallinguistic operations that reflect the logic of law. Through the combination of such approaches innovative insights have been provided in the Russian legal-linguistic research into the fundamentals of the legal language. Moreover, in recent decades a shift from homemade methodology towards adopting more universal methodical standards, especially those close to pragmalinguistics and discourse analysis is discernible in the Russian research. Undeniably, however, also traditional research concepts and methods that are less productive in contemporary legal-linguistic discussion remain in use as well.

\section{References}

Александров, А.С. 2003. Введение в судебную лингвистику. Нижний Новгород: Нижнегородская правовая академия.

Арутюнова, Н.Д., Рябцева, Н.К. (ред.) 1995. Логический анализ языка: Истина и истинность в культуре и языке. Москва: Наука.

Васмер, В. 2003. Этимологический словарь русского языка. (т. IIV) Москва: Астрель/Аст.

Власенко, Н.А. (1997) Язылк права. Иркутск: Восточно-Сибирское книжное издательство.

Голев, Н.Д. (ред.) 2004. Юридические аспекты языка и лингвистические аспекты права. Межвузовсий сборник 
научных статей. Барнаул: .Издательство Алтайского Университета.

Голетиани, Л. 2011. О развитии юридической лингвистики в России и Украине. Studi Slavistici m. VIII: 241-262.

Голетиани, Л. 2016. Выражение деонтической модальности 'обязательство': русские и украинские глагольные конструкции. Comparative Legilinguistics, m. 26: 7-30.

Галдиа, М., Воронина, Н.А. (ред.) 2004. Проблемы прававого регулирования межэтнических отношений и антидискриминационного законодательства в Российской Федерации. Москва: Тасис.

Додонов, В.Н., Каминская, Е.В., Румянцев, О.Г. 1997. Словарь гражданского права. Москва: ИНФРА-М.

Дождев, Д.В. 2003. Римское частное право. Москва: Норма.

Дубровская, Т.В. 2010. Судебный дискурс: речевое поведене судьи (на материале русского и английского языков). Москва: Изд. Академия МНЭПУ.

Дубровская. Т.В. 2014. Судебный дискурс как культурный феномен: национално-культурне особенности речи судей. Вопросы Языкознания, нр. 2: . 76-88.

Зализняк, А., Левонтина, И., Шмелев, А. 2002. Ключевые идеи русской языковой картины мира, в: Отечественные записки, т. 3 (4).

Карский, Е.Ф. 1930. Русская Правда по древнейтему списку. Ленинград.

Климов, Г.А., Халилов, М. Ш. 2003. Словарь кавказских языков. Сопоставление основной лексики. Москва: Восточная Литература РАН.

Кошкин, И.С. 2008. Русско-германские языковые контакты в грамотах северо-запада Руси XII-XV вв. Санкт-Петербург: Издательство Санкт-петербургского университета.

Кусов, Г.В. 2004. Оскорбление как иллокутивный лигвокултурный кониепт, Волгоград.

Милов, Л.В. 1999. Византийская Еклогда и «Правда Ярослава» (К рецепции византийского права на Руси), в: ГENNAAIOC $\kappa$ 70-летию академика Г.Г. Литаврина: 129-142. Индрик: Москва, .

Обнорский, С.П. 1934. «Русская Правда» как памятник русского литературного языка. Известия АН СССР: 776. 
Пиголкин, А.С. (ред.) 1990. Язык закона. Москва: Юридическая Литература.

Платонов, С.Ф. 1917/1996 Лекиий по русской истории. Петроград: Сенатская Типография.

Плотникова, Н.С. (ред.) 2010. “Правда" Дискурсы справедливости в русской интелектуалной истории. Москва: Библиотека Института Справедливыи мир.

Рудоквас, А.Д. 2011. Спорные вопросы учения о приобретательной давности. Москва: Издат. Группа Закон.

Селищев, А.М. 1957. О языке "Русской Правды" в связи с вопросом о древнейшем типе русского литературного языка. Вопросы Языкознания, но. 4.

Смирнов, А.В., Манукян А. Г. 2008. Толкование норм права. Москва: Проспект.

Соколовский, С.В. 2004. Перспективы развития концепщии этнонациональной политики в Российской Федеращии. Москва: Тасис.

Сысоева, И.А., Соболев, А.В. 2014. Терминологические аспекты перевода гражданского кодекса Российской Федерации, в: Филологические науки, нр. 4: 189-191.

Федотов, М.Р.1996. Этимологический словарь чувашского языка, т. I-II. Чебоксары: Чувашский государственный институт гуманитарных наук.

Филиппова, Е.И. 2013. Языки меньшинств: юридический статус и повседневные практики. Москва: Росинформагротех.

Черных, Р.Я. 1953. Язык “Уложения 1649 г.” Москва: Изд. АН CCCP.

Шахматов, А. 1886. Исследование о языке новгородских грамот XIII и XIV века. Иссл. Р. Я. , m. 1, нр 2. С. Петербург.

Ягич, И.В. 1910/2003. История славянской филологии. Москва: Индрик.

Bartoszewicz, Albert. 1979. История русского литературного языка. Warszawa: Państwowe Wydawnictwo Naukowe.

Bräuer, Herbert. 1961. Slavische Sprachwissenschaft. Teil I Einleitung. Lautlehre. Berlin: Walter de Gruyter.

Broekman, Jan M. 1971. Strukturalismus. Moskau-Prag-Paris. Freiburg/München: K. Alber. 
Burukina, Olga. 2012. Legal Language: A Realm of Contradictions. Contemporary Readings in Law and Social Justice, vol. 4: 715.

Casertano, Letizia. 2008. Il linguaggio giuridico russo. In Europa $e$ linguaggi giuridici, ed. M. Timoteo, B. Pozzo, 209-258. Milano: Giuffrè Editore.

Dubrovskaya, Tatiana, Dankova, Natalia, Gulyaykina, Svetlana. 2015. Judicial power in Russian print media: Strategies of representation. Discourse \& Communication, vol. 9(3): 293312.

Ewers, J.P.G. 1826. Das älteste Recht der Russen in seiner geschichtlichen Entwicklung Dorpat: A. Sticinski/Hamburg: F. Perthes.

Freidhof, Günther. 1995. Der Schauprozess als Exemplum forensischer Linguistik. Teil 1. Einführung und Typologie von charakteristischen Sprechhandlungen, In Slawische Sprachwissenschaft und Interdisziplinarität, ed. G. Freidhof, H. Kusse, F. Schindler, F., 7-36. München: O. Sager.

Freidhof, Günther. 1996. Der Schauprozess als Exemplum forensischer Linguistik. Teil 2. Metakommunikation, Metadialog und Master Speech Act. In Slawische Sprachwissenschaft und Interdisziplinarität. ed. Freidhof, G. Freidhof, H. Kusse, F. Schindler, F., 95-131. München: O. Sager.

Galdia, Marcus. Höpp, Karin. 1993. Aspekte der Zweisprachigkeit bei den Finnougriern am Beispiel der Mari und der Komi. Berliner Beiträge zur Hungarologie, vol. 6: 185-194.

Galdia, Marcus. 2014. Legal Discourses. Frankfurt a.M.: P. Lang.

Galdia, Marcu. 2017. Lectures on Legal Linguistics. Frankfurt a.M.: P. Lang.

Glötzner, Victor. 1967. Die strafrechtliche Terminologie des Uloženie 1649. Untersuchungen zur russischen Rechtsgeschichte und Gesetzessprache. Wiesbaden: Harrassowitz.

Goetz, Leopold Karl. 1916. Deutsch-Russische Handelsverträge. Abhandlungen des Kolonialinstituts, vol. 37. Hamburg.

Husa, Jaakko. 2012. Understanding Legal Languages: Linguistic Concerns of the Comparative Lawyers. In The Role of Legal Translation in Legal Harmonization. ed. C.J.W. Baaij, C.J.W. Alphen a.d. Rijn: Wolters Kluwer. 
Korolev, Sergey. 2010. Procedural Misfires of Cross-Cultural Legal Communication in the Perspective of J. Austin and J. Langshaw Austin. Comparative Legilinguistics. International Journal for Legal Communication, vol 4: 27-35.

Lehmann, Volkmar. 2013. Linguistik des Russischen. Grundlagen der formal-funktionalen Beschreibung. München/Berlin/ Washington: O. Sagner.

Lehtinen, Leena. 2008. Venäjän metsäoikeudessa menee helposti metsään. In Kielen ja oikeuden kohtaamisia. Heikki E.S. Mattilan juhlakirja, ed. R. Foley, T. Salmi-Tolonen, I. Tukiainen, B. Vehmas. Helsinki: Talentum.

Mattila, H.E.S. 2012. Jurilinguistique comparée. Langage du droit, latin et langues modernes. Cowansville: Éditions Yvon Blais.

Mattila, H.E.S. 2017. Vertaileva oikeuslingvistiikka. Juridinen kielenkäyttö, lakimieslatina, kansainväliset oikeuskielet. Helsinki: Alma Talent.

Miklosich, Franz. 1888. Die Blutrache bei den Slaven. Denkschriften der Wiener Akademie der Wissenschaften, Philosophischhistorische Klasse, vol. 36. Wien.

Mushchinina, Maria. 2009. Rechtsterminologie - ein Beschreibungsmodell: das Russische Recht des geistigen Eigentums. Berlin: Frank \& Timme.

Napierski, Karl. 1868. Russisch-livländische Urkunden, Petersburg.

Stang, Ch. 1939. Die altrussische Urkundensprache der Stadt Polock. Skrifter utgitt av Det Norske Videnskaps Akademi, II Hist. Filos. Kl., no. 9. Oslo.

Stang, Christian. 1952. Die westrussische Kanzleisprache des Großfürstentums Litauen. Skrifter utgitt av Det Norske Videnskaps Akademi, Hist.-filos. Klasse, no. 2. Oslo.

Unbegaun, B.O. 1957. Russe et slavon dans la terminologie juridique. Revue des études slaves, vol. $34: 135$.

Unbegaun, B.O. 1969. Язык русского права. Selected Papers on Russian and Slavonic Philology. Oxford: Oxford University Press.

Zamyatin, Konstantin. 2014. An Official Status for Minority Languages? A Study of State Languages in Russia's FinnoUgric Republics. Helsinki: University of Helsinki. 